\title{
Natural or anthropogenic? On the origin of atmospheric sulfate deposition in the Andes of southeastern Ecuador
}

\author{
S. Makowski Giannoni, R. Rollenbeck, K. Trachte, and J. Bendix \\ Laboratory for Climatology and Remote Sensing (LCRS), Faculty of Geography, University of Marburg, \\ Deutschhausstr. 12, 35032 Marburg, Germany \\ Correspondence to: S. Makowski Giannoni (sandro.makowski@posteo.org)
}

Received: 4 March 2014 - Published in Atmos. Chem. Phys. Discuss.: 27 May 2014

Revised: 5 September 2014 - Accepted: 15 September 2014 - Published: 28 October 2014

\begin{abstract}
Atmospheric sulfur deposition above certain limits can represent a threat to tropical forests, causing nutrient imbalances and mobilizing toxic elements that impact biodiversity and forest productivity. Atmospheric sources of sulfur deposited by precipitation have been roughly identified in only a few lowland tropical forests. Even scarcer are studies of this type in tropical mountain forests, many of them megadiversity hotspots and especially vulnerable to acidic deposition. In these places, the topographic complexity and related streamflow conditions affect the origin, type, and intensity of deposition. Furthermore, in regions with a variety of natural and anthropogenic sulfur sources, like active volcanoes and biomass burning, no source emission data has been used for determining the contribution of each source to the deposition. The main goal of the current study is to evaluate sulfate $\left(\mathrm{SO}_{4}^{-}\right)$deposition by rain and occult precipitation at two topographic locations in a tropical mountain forest of southern Ecuador, and to trace back the deposition to possible emission sources applying back-trajectory modeling. To link upwind natural (volcanic) and anthropogenic (urban/industrial and biomass-burning) sulfur emissions and observed sulfate deposition, we employed state-of-the-art inventory and satellite data, including volcanic passive degassing as well. We conclude that biomass-burning sources generally dominate sulfate deposition at the evaluated sites. Minor sulfate transport occurs during the shifting of the predominant winds to the north and west. Occult precipitation sulfate deposition and likely rain sulfate deposition are mainly linked to biomass-burning emissions from the Amazon lowlands. Volcanic and anthropogenic emissions from the north and west contribute to occult precipitation sulfate deposition at the mountain crest Cerro del Consuelo meteorological station
\end{abstract}

and to rain-deposited sulfate at the upriver mountain pass El Tiro meteorological station.

\section{Introduction}

Sulfur enters the atmosphere principally as sulfur dioxide $\left(\mathrm{SO}_{2}\right)$, an air pollutant with a lifetime of about 1 to 2 days, before it is normally deposited or oxidized into sulfate $\left(\mathrm{SO}_{4}^{-}\right)$. After oxidation, lifetime increases to 3 or more days, depending on the state of the atmosphere and the injection height. Because of its longer lifetime, sulfate can be spread over greater distances. In high concentrations, sulfate decreases the $\mathrm{pH}$ of precipitation to levels that represent a threat to health and ecosystems. This phenomenon called "acid rain" has been discussed in the past, particularly in the industrialized countries of Europe and North America where adverse effects were found to be more serious for health than for ecosystems (Menz and Seip, 2004).

In tropical ecosystems, only a few studies are available despite the fact that they are mostly characterized by an interference-prone biogeochemical cycle and nutrient limitation (Elser et al., 2007; Wullaert et al., 2010), and hence particularly sensitive to acid deposition (Boy et al., 2008; Delmelle et al., 2002). Kuylenstierna et al. (2001), for example, revealed that acidification from atmospheric sulfur could represent a threat to tropical ecosystems in developing countries. Acidification of soil due to persistent increases in sulfate inputs could lead to nutrient imbalances and changes in ecosystem diversity and productivity (Greaver et al., 2012; Phoenix et al., 2006). It can also mobilize many potentially toxic elements that promote soil degradation and erosion 
in some areas. Acid and toxic elements can leach out of the soil by rain and go into groundwater and nearby water bodies (Ljung et al., 2009). Considering these adverse effects of acidic deposition in land ecosystems, serious impacts can be expected, especially in highly biodiverse and disturbance-sensitive forest ecosystems. The probability that undisturbed tropical forests suffer from these detrimental impacts increases if we bear in mind that emissions and related deposition in developing countries, where most of megadiverse tropical forests are found, are rapidly intensifying and that $50-80 \%$ of the fraction of deposition on land falls on natural vegetation (Dentener et al., 2006).

Regarding the sources of deposition, $\mathrm{SO}_{2}$ is emitted from different natural and anthropogenic processes. Volcanoes are considered the most important natural sources representing around 26-35\% of total global emissions (Graf et al., 1997; Stevenson et al., 2003). The most important anthropogenic sources are fossil fuel combustion for energy production, transportation, and industrial activities in big cities and their surroundings, and biomass burning from deforestation, land clearing, and bush fires (Lee et al., 2011; Smith et al., 2011). The contribution of each to the total $\mathrm{SO}_{2}$ emissions may vary depending on the region and its developmental state (industrial or industrializing countries). However, in some tropical regions (e.g., Ecuador) volcanic emissions and biomass burning might contribute larger amounts as a consequence of the density of active volcanoes (Carn et al., 2008) and an accelerated land use change mostly characterized by deforestation for creating arable land (Crutzen and Andreae, 1990; Rudel et al., 2005).

On a local to regional scale, detailed knowledge on pollutant deposition from rain and cloud water in specific regions, its sources, and its smaller-scale spatial variability, particularly in complex terrain as that of the Andes, is still scarce. To date, only few studies on atmospheric acidic deposition exist for tropical ecosystems and those including a characterization of source emissions are very rare.

Precipitation chemistry surveys in some montane but mainly lowland tropical forests of Costa Rica, Venezuela, Puerto Rico, Cameroon, and Brazil have characterized nutrient and pollutant deposition by analyzing ionic concentrations, sulfate among others, and in situ meteorological parameters. In Venezuela and Cameroon, Morales et al. (1998) and Sigha-Nkamdjou et al. (2003) indicated the relative importance of local sources, such as biogenic sulfur oxidation by swamps and lakes, to sulfate deposition. However, industrial emissions were indicated as the most important source of sulfate deposition in Venezuela. The opposite was found by Eklund et al. (1997) and Gordon et al. (1994) in Costa Rica and Puerto Rico, respectively, where no significant pollution footprints where found in the samples of the two studied tropical mountain forests. The same was noticed by Pauliquevis et al. (2012) in the central Amazon of Brazil, where high sulfate loads in rainwater likely stem from the oxidation of sulfur compounds from the Atlantic Ocean.
In areas with an important number of active volcanoes like Indonesia, Costa Rica, and Nicaragua, volcanic emissions were given special attention as contributors of acidic sulfate deposition in the surrounding areas and downwind of the emitting craters (Delmelle et al., 2001, 2002; Langmann and Graf, 2003; Pfeffer et al., 2006). For central Africa and tropical South America, however, emissions from burning forests, savannas, and agricultural fields were claimed to be the principal source of atmospheric pollution (Hansen et al., 2013; Rissler et al., 2006; van der Werf et al., 2010) and reactive sulfur deposition in the downwind regions (Diehl et al., 2012; Fabian et al., 2005).

With regard to the mega-diverse tropical mountain rain forest in the southeastern Ecuadorian Andes (Bendix and Beck, 2009), biomass burning in the Amazon has been hitherto identified as the principal source of atmospheric sulfate deposition (Beiderwieden et al., 2005; Boy et al., 2008; Fabian et al., 2005, 2009; Rollenbeck et al., 2011). However, volcanic and biomass-burning emissions were included by roughly estimated data. Given the dense concentration of active volcanoes in Ecuador, where as much as $95 \%$ of emissions can stem from non-eruptive degassing, and considering the difference in emissions between burned areas depending on land use type, it is of utmost importance to include data on source emissions as accurate as possible to characterize air mass pollution history leading to the deposition. Furthermore, preliminary work on nitrogen deposition has shown that crest areas considerably differ in their behavior from valley sites (Makowski Giannoni et al., 2013). Hence, a comprehensive deposition analysis must not only investigate sinks and source intensities but should also study different topographic positions.

Consequently, the main aim of the current study is (1) to determine sulfate deposition at two different topographic positions in the mountain rain forest of southern Ecuador and (2) to trace back the deposition to different natural and anthropogenic emission sources applying back-trajectory modeling. To link the spatiotemporal patterns of upwind natural (volcanoes) and anthropogenic (urban/industrial and biomass-burning) sulfur emissions to sulfate deposition at site, we used the latest state-of-the-art inventories and satellite data and also considered volcanic passive degassing.

\section{Geographical setting}

The Reserva Biológica San Francisco (RBSF) $\left(4^{\circ} 00 \mathrm{~S}\right.$ and $79^{\circ} 00 \mathrm{~W}$ ) is located in a remote area at the outer edge of the Amazon, on the eastern slopes of the southern Ecuadorian Andes, between the humid Amazon plains and the dryer inter-Andean valleys. The RBSF lies within the small San Francisco River catchment between the capital cities of Loja and Zamora (Fig. 1). Since 2002, the protected forest and the pastures outside of the reserve have been the subject of investigations from two successive multidisciplinary research 

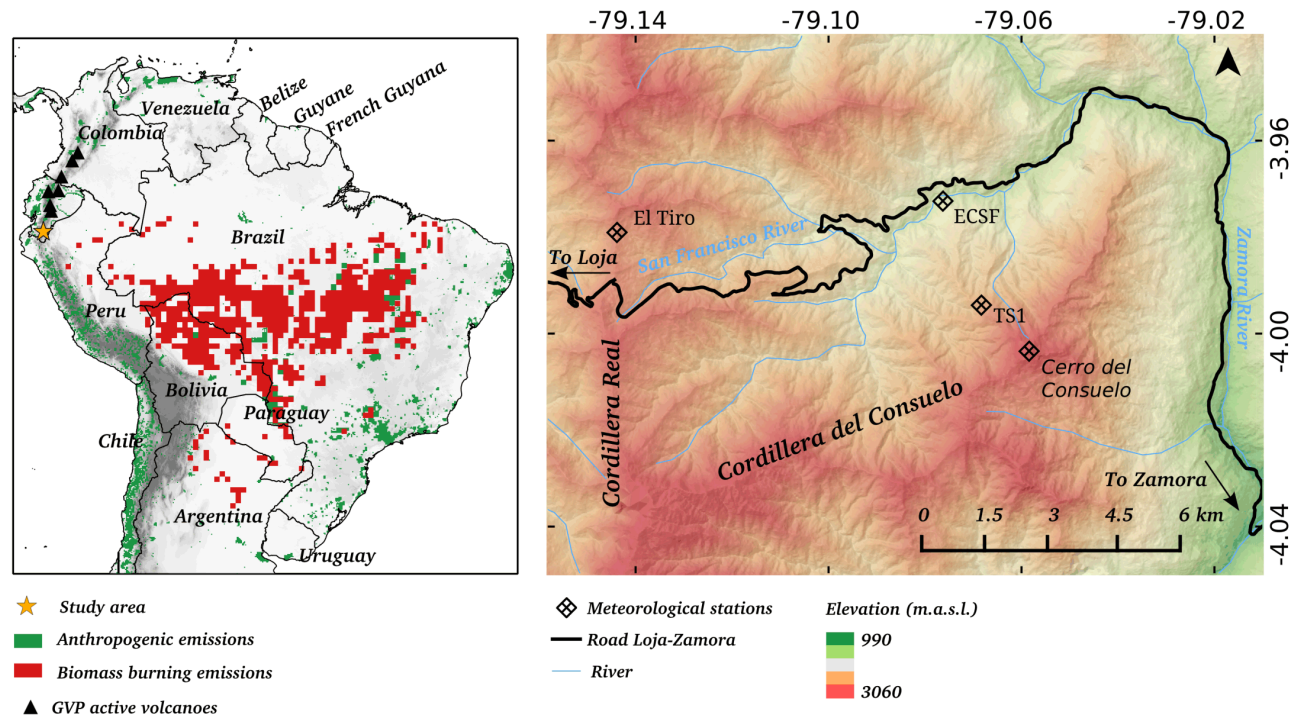

Figure 1. Study area. The left map shows possible anthropogenic and biomass-burning $\mathrm{SO}_{2}$ sources in tropical South America and the location of active volcanoes in Ecuador and Colombia. The right map depicts the study area in the River San Francisco catchment and the location of the meteorological stations (MSs) involved in the study.

groups funded by the German Research Council (DFG) (Beck et al., 2008; Bendix et al., 2013). The terrain height of the area is lower compared to the northern and southern Andes and its topography more complex, as the system of few parallel mountain ranges gives way to a net of small valleys and cordilleras (Rollenbeck et al., 2011).

There are only a few sources of pollution in the vicinity of the RBSF. The cities of Loja $(\sim 214855$ inhabitants, $10 \mathrm{~km}$ to the west; INEC, 2010) and Zamora $(\sim 25510$ inhabitants, $14 \mathrm{~km}$ southeast; INEC, 2010) are quite small and without any notable industrial activity. Between October and December, a relative dry season, slash-and-burn techniques are a common practice in local pasture management which quite often runs out of control, burning adjacent areas of forest (Bendix et al., 2008b; Curatola Fernández et al., 2013; Hartig and Beck, 2003).

The synoptic winds at the upper levels of the cordillera consist of tropical easterly trades over more than $70 \%$ of the year. Northeasterlies prevail between January and March while southeasterlies dominate between June and September. The remaining $30 \%$ of the year corresponds with the westerlies and northerlies, mainly occurring between the end of October and December (Bendix et al., 2008a; Emck, 2007).

Precipitation varies, mainly depending on the migration of the Intertropical Convergence Zone (ITCZ) and the variation in the direction of the tropical easterlies. The associated humidity advection dominates the amount of atmospheric water entering the ecosystem. The total annual average of rainfall (rainfall and occult precipitation) range from 1850 to $6300 \mathrm{~mm}$ year $^{-1}$ along an altitudinal gradient of between 1960 and $3180 \mathrm{~m}$ a.s.l. Occult precipitation (OP) frequencies of up to $85 \%$ of the year occur particularly in the more el- evated parts of the research area, when warm and humid air masses from the Amazon lowlands hit the Andes, leading to intense condensation and immersion in clouds (Bendix et al., 2006a, b; Emck, 2007; Rollenbeck, 2010).

\section{Data and methods}

In the present study, we discuss the variation of sulfate concentration/deposition in precipitation in a 5-year period (2005-2009) at two meteorological stations (MSs). Higher locations are more vulnerable to higher deposition (Makowski Giannoni et al., 2013), hence the selection of the two highest MSs in the RBSF for this study. Because of the strong winds at the locations of sampling, we will refer to all types of light precipitation, from wind-driven drizzle down to fog and cloud droplets as OP.

For studying source-receptor relationships, we brought together measurements of sulfate concentrations in rain and $\mathrm{OP}$ samples with back-trajectory transport modeling using satellite and emission inventories as inputs. The modeling of $\mathrm{SO}_{2}$ transport, hereinafter referred to as " $\mathrm{SO}_{2}$ transport", results in $\mathrm{SO}_{2}$ daily concentration values at the target coordinates which match the observation sites

The following section (3.1-3.2) is devoted to a detailed description of the data and methods used. Section 3.2.2 mentions and discusses the techniques employed to unveil the relationships between in situ observations and transport to the observation sites. 


\subsection{Data}

\subsection{Sulfate in rain and $O P$}

We measured rainfall and OP at two MSs: one installed on the highest surrounding peak (Cerro del Consuelo, $3180 \mathrm{~m}$ a.s.l.) and the other one on an upriver mountain pass (El Tiro, $2870 \mathrm{~m}$ a.s.l.), separating the basin of Loja in the west from the eastern slopes of the Andean mountain range (Fig. 1).

The collection of samples was conducted on a weekly basis between 2005 and 2009. Rain was sampled using UMSRS 200 polyethylene rain samplers of $20 \mathrm{~cm}$ diameter. Standard fog collectors (Schemenauer and Cereceda, 1994) were used to sample OP. With a size of $1 \times 1 \mathrm{~m}$ and composed of polypropylene nets with a $2 \times 1 \mathrm{~mm}$ mesh width, they were set up at $90^{\circ}$ with respect to the main wind direction and collected all types of deposition, such as particles, aerosols, and gases (Fabian et al., 2005).

We did not use wet-only collectors, so dry deposition likely adds to the total deposition. For the fog collectors, Schemenauer et al. (1995) estimated the contribution of dry deposition to the total deposition to be less than $5 \%$ for temperate mountain forests of North America. Because of the very humid conditions at our study site (high frequency of cloud immersion, around $85 \%$ of the time, Bendix et al., 2008a) and the dense vegetation cover, which implies no sources for turbulent generation of local aerosol, dry deposition's contribution is most probably negligible for fog collectors (very probably less than that found by Schemenauer et al., 1995) and rain gauges. Considering that one of our goals is to evaluate sulfate inputs into the ecosystem, the catching efficiency from collectors in relation to trees is also an important parameter. For this, Schemenauer and Cerceda (1994) found good agreements between the collection rates of different tree species and the standard fog collectors that we used in this study. For further details on field measurement techniques, calibration, and handling of the data, the reader is referred to Fabian et al. (2005) and Rollenbeck et al. $(2007,2011)$. On the day of collection, electrical conductivity (WTW-LF 90) and pH (Methron 73065/682) of the samples were measured on site. Then, the samples were stored deep frozen until chemical analyses were carried out.

Ion chromatography (Dionex DX-210) was used to measure concentrations of sulfate ions in rain and OP water. The sulfate ions were taken as proxies of sulfur inputs into the ecosystem. Finally, time series of sulfate volume-weighted monthly mean (VWMM) concentrations and total deposition rates in rain and OP water were created for the period 20052009.

\section{$3.3 \quad \mathrm{SO}_{2}$ source data}

We used three recent emission inventories and one satellite data set as emission inputs to simulate the $\mathrm{SO}_{2}$ transport to our study area: (a) one for anthropogenic emissions
(EDGARv4, Janssens-Maenhout et al., 2012), (b) one for biomass-burning emissions (Global Fire Emissions Database (GFED) v3, Mu et al., 2011), and (c) one for emissions from volcanic degassing and explosive eruptions (Aerocom, Diehl et al., 2012). The ozone monitoring instrument (OMI) $\mathrm{SO}_{2}$ data accounts mostly for $\mathrm{SO}_{2}$ emissions from volcanoes, including passive degassing, but very strong anthropogenic pollution events are also detected by the sensor (Carn et al., 2007, 2008).

a. The emissions in EDGARv4 are calculated using a technology-based emission factor approach which includes country-specific emissions when these are available. Emissions are allocated spatially on $0.1 \times 0.1^{\circ}$ grid cells for point, line, and area sources built upon geographic data sets such as the location of energy and manufacturing facilities, road networks, and population density. In version 4, EDGAR delivers annual emission estimates from 1970 to 2008, which represents an improvement compared to former static inventories. For more information readers may visit the EDGAR website (http://edgar.jrc.ec.europa.eu/index.php).

b. For biomass-burning $\mathrm{SO}_{2}$ estimates, we used the GFEDv3 inventory. The compilation of this inventory was based on a biogeochemical model (CASA-GFED) that approximates fuel loads and combustion completeness for each time step, and burned area data from satellite observations (van der Werf et al., 2010). Considering that fires are very often sporadic and transient, the high temporal and spatial resolution appear very advantageous when dealing with the variation of emissions in space and time. Some issues which might reduce the regional quality are the underestimation of emissions in the tropics because of cloud cover and canopy closeness, and gaps in the satellite coverage.

c. As part of the Aerocom global emission inventories, a daily resolved volcanic $\mathrm{SO}_{2}$ emission data set was generated for the time period 1979-2009, including all volcanoes with historic eruptions listed in the Global Volcanism Program (http://www.volcano.si.edu/). Since volcanic emissions are in some cases occasional, the high temporal resolution of the inventory is indispensable for capturing the variability in the emission rates. Emissions for 1167 volcanoes considered to be active were compiled. The emissions originating from passive and quiescent degassing are also taken into account. The default $\mathrm{SO}_{2}$ estimates are based on the volcanic sulfur index (VSI). In cases where data from the total ozone mapping spectrometer (TOMS), OMI, or the correlation spectrometer (COSPEC) were available, the respective values were replaced by emissions calculated from these observations. In other cases the default values were replaced by more precise estimations from the literature. For more information on the 
Aerocom volcanic $\mathrm{SO}_{2}$ inventory, readers are referred to Diehl et al. (2012) and the Aerocom website (http: //aerocom.met.no/emissions.html).

The OMI on board the polar-orbiting AURA satellite is a nadir solar backscatter spectrometer with a spatial footprint of $13 \times 24 \mathrm{~km}$ that covers the earth's surface in 1 day. The instrument's UV-2 channel, which is used for the $\mathrm{SO}_{2}$ retrievals, has a mean spectral resolution of $0.45 \mathrm{~nm}$. Both its spatial and spectral resolution and its daily global coverage allow for a $\mathrm{SO}_{2}$ retrieval-based monitoring of low emission sources like volcanic passive degassing and smelter plumes which was not possible with older instruments like TOMS or Global Ozone Monitoring Experiment (GOME) . OMI $\mathrm{SO}_{2}$ data has already been successfully applied for daily monitoring of volcanic degassing in Ecuador (Carn et al., 2008) and the detection of $\mathrm{SO}_{2}$ emissions from Peruvian copper smelters (Carn et al., 2007). Although the OMI instrument cannot distinguish between anthropogenic and volcanic $\mathrm{SO}_{2}$ when co-occurring in close vicinity, Carn et al. (2007) concluded that anthropogenic sources in the coastal plains of Ecuador would only contribute less than $1 \%$ to the total amount measured by OMI. In the current study, we used subsets of the OMI data replicating the same geographical domain defined by Carn et al. (2008) for Ecuadorian volcanic emissions. The region selected is not affected by the South Atlantic anomaly, an artifact impacting the retrievals of a big area in central and southern South America (Lee et al., 2011); this means that OMI retrievals are reliable in the selected domain. The concentration retrieved by OMI was assumed to represent mainly the Ecuadorian volcanic emissions' contribution to the atmospheric $\mathrm{SO}_{2}$ concentrations. Given its small geographic domain, the OMI data is set to account for regional emissions from Ecuador and southern Colombia.

\subsection{Methods}

\subsection{Trajectory modeling}

To link potential $\mathrm{SO}_{2}$ source regions with the sulfate concentration measurements at our study site, a tool was developed which models the transport of $\mathrm{SO}_{2}$ from upwind sources (biomass-burning, anthropogenic, and volcanic emissions) to our receptor area. The tool follows the path of the wind trajectories and adds the emission amounts from the pixels that prove spatial and temporal coincidence until a target point, which corresponds with the coordinates of the RBSF. No chemical or physical transformations are included in the modeling scheme. Scavenging and rainout processes are accounted for by a decay function integrated into the algorithm. For more details on the tool refer to Rollenbeck (2010) and Makowski Giannoni et al. (2013).
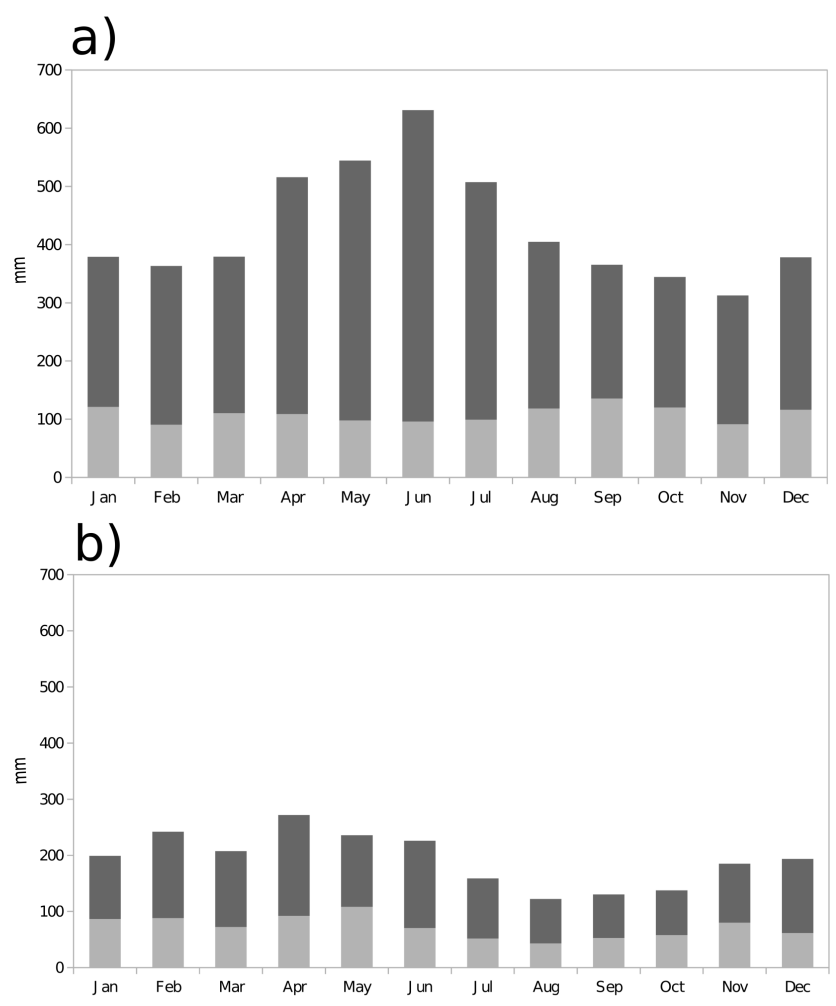

Figure 2. Rain (dark grey) and occult precipitation (OP) (light grey) monthly means for (a) Cerro del Consuelo and (b) El Tiro meteorological stations (MSs).

\subsection{Observation and model data processing and evaluation}

To calculate best estimates of precipitation (rain and OP), we used a method similar to the one used in the Goddard Institute for Space Studies Surface Temperature Analysis (GISTEMP, Hansen et al., 2010). Nearby MSs were used to evaluate unrealistic values and to fill in data gaps of the MSs that we used in this study.

Time series of volume-weighted conductivity and $\mathrm{pH}$ monthly means were compiled and summary statistics such as median, median absolute deviation (MAD), and minimum and maximum values were calculated. For sulfate concentrations in both types of precipitation, VWMM were also calculated and time series covering the whole observation period were built. Here, we identified the time span in which peak values or regular phenomena took place, as well as long-term trends. All time series were then compared to check for acidification of the samples when highly loaded with sulfate ions.

Additionally, we calculated and analyzed annual mean deposition rates for El Tiro and Cerro del Consuelo MSs as having a measure of sulfate input variability per unit area, which is important for assessing potential impacts on ecosystems by a nutrient manipulation experiment (NUMEX, Homeier et al., 2012). 
For source-receptor analysis, the daily transport model outputs were first aggregated according to the dates of sample collection in the field, in order to achieve comparable values for time series compilation and correlation analysis. We calculated the mean weekly values to compensate for irregular time intervals between the collection of samples. We then used these new values to calculate $\mathrm{SO}_{2}$ transport monthly averages and to compile transport time series from the different emission sources represented by the emission inventories and satellite data. Before proceeding with statistical analysis, all the data was transformed to a logarithmic scale to approach normality. We then carried out a Pearson correlation analysis to test for correlations between field observations (VWMM sulfate concentrations) and model outputs ( $\mathrm{SO}_{2}$ transport); we used VWMM and not deposition values to avoid extra uncertainty added by new variables present in the deposition calculations. Finally, visual analysis of coincidences between transport and VWMM concentration time series was performed, taking into account events which could influence the transport of sulfate and its deposition into our study area.

In addition to the bivariate correlation analysis, we applied a factor analysis with varimax rotation to test for variance explanation from groups of variables.

\section{Results}

\subsection{Emission sources and annual deposition}

The highest precipitation and OP inputs were registered from April to July at Cerro del Consuelo MS (Fig. 2a), and in February and from April to June at El Tiro MS (Fig. 2b). A short dry season took place between September and November. Rain quantity varied significantly between dry and wet periods while OP inputs remained quite constant at around $100 \mathrm{~mm}$ for both MSs over the whole observation period.

The calculated volume-weighted monthly $\mathrm{pH}$ values in samples from Cerro del Consuelo MS yielded median values of 5.3 and 5 with a median absolute deviation (MAD) of 0.36 and 0.29 in rain and OP, respectively (Table 1). The water samples in both types of precipitation input tended to be acidic with some extreme values going as low as 1.86 in OP samples and 3 in rain samples. Occult precipitation sulfate concentration presented a negative and weak, but significant, correlation with $\mathrm{pH}$ values (Pearson, $r=-0.34, p<0.05$ ). Conductivity values ranged between 1.4 and $72 \mathrm{~S} \mathrm{~m}^{-1}$, with median values of 2.6 and $8.1 \mathrm{~S} \mathrm{~m}^{-1}$ in OP and rain, respectively. The bulk of the data ranged, nevertheless, between 1.4 and $14.3 \mathrm{~S} \mathrm{~m}^{-1}$. Conductivity is a proxy of ion concentrations in water and thus, high conductivity values coincide with episodes of rain and OP water droplets with high ion loads.

In samples from El Tiro MS, $\mathrm{pH}$ volume-weighted values were in the acidic area of the spectrum too, with median values of 5.4 and 4.8 and MAD of 0.51 and 0.37 in rain and OP, respectively (Table 1). There was a strong negative correlation between sulfate concentration in OP and $\mathrm{pH}$ (Pearson, $r=-0.64, p<0.001)$, and a weaker one for sulfate concentration in rain (Pearson, $r=-0.34, p<0.05$ ). Median conductivity values were generally higher when compared to those at Cerro del Consuelo MS. They yielded a median of 10.9 and $3.7 \mathrm{~S} \mathrm{~m}^{-1}$ in OP and rain, respectively. As opposed to what we observed at Cerro del Consuelo MS, conductivity was much higher in OP than in rain at El Tiro MS, meaning a strong ion load; values ranged between 1.4 and $110.3 \mathrm{~S} \mathrm{~m}^{-1}$.

Figure 3 shows the annual sulfate deposition by rain and $\mathrm{OP}$ at (a) Cerro del Consuelo and (b) El Tiro MSs. The deposition was generally higher for the Cerro del Consuelo MS for both types of precipitation. The only exception was the year 2009 where the OP deposition at El Tiro MS increased significantly in comparison to a decrease at Cerro del Consuelo MS. The highest amount of sulfate was deposited by rain in 2007 at the Cerro del Consuelo MS. Lowest burden was observed in rain samples from El Tiro MS in 2009. The figure shows that El Tiro MS was experiencing higher annual deposition rates by $\mathrm{OP}$ over nearly all years, pointing to a more advective environment. In contrary, Cerro del Consuelo MS was characterized by changing deposition maxima between rain and OP over time.

A tendency towards lower OP sulfate deposition (light grey bars) was observed in Fig. 3, with an upturn in 2009 for El Tiro MS. Deposition by rain (dark grey bars) was more oscillating, especially in the quantities deposited at Cerro del Consuelo MS. After 2008, a negative tendency in rain deposition became clearer.

Concerning the emissions, Fig. 4 depicts 5-year average maps of emissions for every data set used for simulating transport. From a rather local perspective, emissions from volcanoes appeared to be intense mainly close to the most active volcanoes: Sangay, Tungurahua, and Reventador (Fig. 4a). Emissions from big cities were only evident for the metropolitan region of Guayaquil and Quito. Still, much of the air above the region of Guayaquil and the coast of Ecuador seems to have been contaminated with $\mathrm{SO}_{2}$ emissions from volcanoes, which plumes were transported principally to the west and southwest and cover part of the ocean next to the southern coast of the country. The strong emissions east of Reventador most probably originate from deforestation activities. The high emission pixels at the same location in the biomass-burning data set (Fig. 4c) support this argument.

Figure $4 \mathrm{~b}$ shows volcanic emissions from eruptions and passive degassing. Once again, Sangay, Tungurahua, and Reventador belong to the volcanoes that contribute the most to emissions in Ecuador. In Colombia, the Nevado del Huila and Galeras volcanoes are the strongest $\mathrm{SO}_{2}$ emitters. For biomass burning, the main region is located in the Brazilian and Bolivian Amazon (Fig. 4c). The Venezuelan savanna in the northeast is another important biomass-burning region. The majority of potential anthropogenic sources (industrial, 
Table 1. $\mathrm{pH}$ and conductivity summary statistics in occult precipitation (OP) and rain samples from El Tiro and Cerro del Consuelo meteorological stations (MSs).

\begin{tabular}{lrr|rr}
\hline & \multicolumn{2}{c|}{ El Tiro } & \multicolumn{2}{c}{ Cerro del Consuelo } \\
\cline { 2 - 5 } & OP & Rain & OP & Rain \\
\hline Median $\mathrm{pH}$ & $4.8 \mathrm{MAD}=0.37$ & $5.4 \mathrm{MAD}=0.51$ & $5 \mathrm{MAD}=0.29$ & $5.3 \mathrm{MAD}=0.36$ \\
Min-max pH & $2.4-5.8$ & $3.7-6.7$ & $1.8-6.2$ & $3-6.1$ \\
Median conductivity $\left(\mathrm{S} \mathrm{m}^{-1}\right)$ & $10.9 \mathrm{MAD}=6.4$ & $3.7 \mathrm{MAD}=1.6$ & $2.6 \mathrm{MAD}=1$ & $8.1 \mathrm{MAD}=6.8$ \\
Min-max conductivity $\left(\mathrm{S} \mathrm{m}^{-1}\right)$ & $2.3-110.3$ & $1.4-45.4$ & $1.4-12.4$ & $1.7-72$ \\
\hline
\end{tabular}

a)

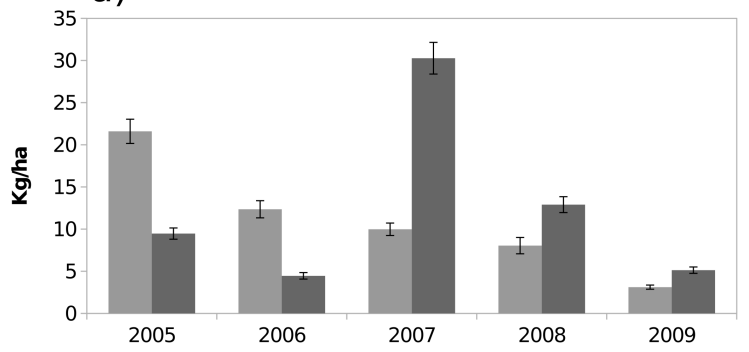

b)

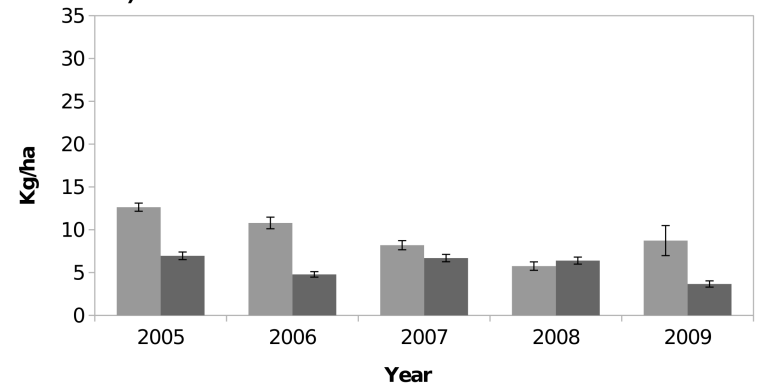

Figure 3. Total yearly sulfate $\left(\mathrm{SO}_{4}^{-}\right)$deposition at (a) Cerro del Consuelo and (b) El Tiro meteorological stations (MSs). Dark grey bars represent deposition by rain and light grey bars, deposition by occult precipitation (OP).

urban, and transportation) are located in the north of our study area (Fig. 4d). This occurs because of the extreme scarcity of significant sources in the east and because no air masses arriving to our study area originate and pass over the sources from the south.

\subsection{Linking emissions to deposition}

\subsection{Correlation analyses}

A first test, using a cross-correlation technique, is required to unveil the dependence of the transport data sets. This is shown in Table 2. Only moderate correlations for El Tiro and somewhat higher correlations for Cerro del Consuelo were revealed by this analysis. As expected, volcanic and anthropogenic source concentrations correlate well, while only low (partly negative) correlations between biomass- burning and anthropogenic and volcanic pollutant transport is visible. This means that there is some overlap in the data sets related to volcanic and anthropogenic emissions. The negative correlation between anthropogenic and biomassburning emissions could indicate that their transport depends on changing wind directions (east for biomass-burning, north and west for anthropogenic) which means that the anthropogenic sources affecting the area are located more in the western and northern sectors.

To connect sinks with sources, correlation analysis between atmospheric $\mathrm{SO}_{2}$ concentrations in the pixel representing the location of the observation site, derived by backtrajectory modeling, and the measured sulfate concentrations was conducted. Pearson's correlation coefficients calculated for sulfate concentration and $\mathrm{SO}_{2}$ transport are presented in Table 3. It is observed that, even if significant, the correlations between source and sink data are generally low.

For the Cerro del Consuelo crest site, it is interesting to see that more evident correlations occur between OP and volcanic emissions. Because OMI includes volcanic emissions, it shows the second highest correlation coefficient for OP. The link to biomass burning seems to be generally weak at this altitude and topographical location of the cordillera.

The situation changes for the up-valley El Tiro MS, where the highest correlations occur between rain concentrations and anthropogenic sources and between OP concentrations and biomass-burning sources.

Even if the correlation coefficients are low, they show interesting tendencies. For the El Tiro site, volcanic and anthropogenic emissions are more clearly related to rain concentrations while the opposite is true for biomass-burning emissions, which is more strongly related to OP concentrations. OMI shows a mixed behavior because it includes volcanic as well as regional anthropogenic emissions as shown in Table 2 and Fig. 4.

Rather low correlation coefficients imply that no unique source can totally explain the oscillations in the concentrations. Furthermore, correlation coefficients are blurred because peaks are extreme values, which represent scatter. The concentration time series are a sum curve of all transport values. By exploring time series of sink and transport from sources, the next Sect. (4.2.2) sheds some light on what 
Table 2. Cross-correlation of calculated $\mathrm{SO}_{2}$ concentration time series over El Tiro and Cerro del Consuelo $\mathrm{SO}_{2}$ transport pixels using the different emission data sets.

\begin{tabular}{|c|c|c|c|c|}
\hline & $\left.\begin{array}{r}\text { Biomass-burning } \\
(\text { GFED SO} \\
2\end{array}\right)$ & $\begin{array}{r}\text { Regional volcanic and } \\
\text { strong anthropogenic }\left(\mathrm{OMI} \mathrm{SO}_{2}\right)\end{array}$ & $\begin{array}{r}\text { Volcanic } \\
\left(\text { Aerocom } \mathrm{SO}_{2}\right)\end{array}$ & $\begin{array}{l}\text { Anthropogenic } \\
\left(\text { EDGAR SO }_{2}\right)\end{array}$ \\
\hline \multicolumn{5}{|l|}{ (a) Pixel El Tiro } \\
\hline Biomass-burning $\left(\mathrm{GFED} \mathrm{SO}_{2}\right)$ & 1 & & & \\
\hline $\begin{array}{l}\text { Regional volcanic and } \\
\text { strong anthropogenic }\left(\mathrm{OMI} \mathrm{SO}_{2}\right)\end{array}$ & 0.01 & 1 & & \\
\hline Volcanic (Aerocom $\left.\mathrm{SO}_{2}\right)$ & 0.14 & $0.42^{* * *}$ & 1 & \\
\hline Anthropogenic (EDGAR SO${ }_{2}$ ) & $-0.29^{*}$ & $0.52^{* * *}$ & $0.66^{* * *}$ & 1 \\
\hline \multicolumn{5}{|l|}{ (b) Pixel Cerro del C. } \\
\hline Biomass-burning $\left(\mathrm{GFED} \mathrm{SO}_{2}\right)$ & 1 & & & \\
\hline $\begin{array}{l}\text { Regional volcanic and } \\
\text { strong anthropogenic }\left(\mathrm{OMI} \mathrm{SO}_{2}\right)\end{array}$ & $0-0.13$ & 1 & & \\
\hline Volcanic (Aerocom $\mathrm{SO}_{2}$ ) & 0.13 & $0.60^{* * *}$ & 1 & \\
\hline Anthropogenic (EDGAR SO${ }_{2}$ ) & $0-0.35^{* *}$ & $0.69^{* * *}$ & $0.76^{* * *}$ & 1 \\
\hline
\end{tabular}

Note: ${ }^{*} p<0.05,{ }^{* *} p<0.01,{ }^{* * *} p<0.001$.

groups of transport variables explain the most of the variability in the concentration variables.

\subsection{Analysis of monthly time series}

Figure 5 shows the time series of $\mathrm{SO}_{2}$ transport (concentrations at the pixels above the study site) and the respective sulfate concentrations observed at the sites. We observed that mainly depending on emission state and air mass history, emission peaks resulted in concentration peaks of different intensity. One general finding is that the peak concentrations in biomass-burning transport were $\sim 56$ times higher than those of the other sources. Besides this there was a slight tendency of increasing emissions from anthropogenic, regional, and even volcanic sources in the observation period. At the same time, emissions due to biomass burning decreased, particularly in the last years of the study period (2008 and 2009) which is consistent with deforestation statistics in Brazil (Hansen et al., 2013; Rodrigues-Ramos et al., 2011; Torres et al., 2010).

Regarding the relationship between wind direction and the link between sources and sinks, it is obvious that during easterly airstreams coinciding with the Amazon biomass-burning season from August to October (dark grey bars) (Andreae et al., 2004), biomass emission peaks caused concentration peaks. Contrary to this, during wind conditions from the northern and western sector (light grey), peaks in volcanic activity and anthropogenic emissions in central/northern Ecuador is clearly related to concentration peaks.

El Tiro MS had higher sulfate loads in fog than in rain. A decrease following the reduction in biomass burning was observed in the OP sulfate concentration time series from 2007 to 2008 , with a violent upturn at the end of the biomassburning season of 2009 (Fig. 5a) for which we have not found any explanation yet; this last peak is responsible for the light positive tendency of the curve. Rain sulfate time series (Fig. 5b) presented a small negative tendency over the observed period (2005-2009).

In OP, only one peak in the biomass-burning time series (July 2008) seemed to dominate the resulting concentrations. Volcanic transport did not play a role. In rain, biomassburning and volcanic transport peaks were both reflected in the concentration time series, with a stronger coincidence with volcanic emissions. Anthropogenic sources and rainwater sulfate concentrations showed the same peak coincidences at El Tiro MS during northerly winds (particularly in 2005 and 2008). However, volcanic transport was quantitatively higher than that from anthropogenic sources, which means that it likely contributes more to the deposition.

At the uppermost and more-exposed Cerro del Consuelo MS we observe a different situation, namely a very small negative tendency in the sulfate concentrations in both OP (Fig. 5a) and rain (Fig. 5b). Occult precipitation sulfate concentrations are also higher than in rain here. In this case, the negative tendency of the biomass-burning $\mathrm{SO}_{2}$ transport with the highest transport (Fig. 5e) seems to dominate the concentration's temporal development irrespective of the type of precipitation. Biomass-burning peaks affect only rain concentrations, except for one emission peak in August 2005, which affects both OP and rain concentrations (this is more or less the same for El Tiro MS). Interestingly, volcanic transport peaks (Fig. 5d) mostly affect OP concentrations. This is definitely different from El Tiro MS, where no influence in OP concentrations was noticed. EDGAR anthropogenic transport (Fig. 5f) is nonetheless also reflected in OP concentrations, but again here the transport was quantitatively lower. 
Table 3. Cross-correlation matrix for $\mathrm{SO}_{2}$ transport concentrations above El Tiro and Cerro del Consuelo pixels and sulfate concentrations from meteorological stations (MSs) at these two sites, located on an upriver mountain pass and on the highest catchment peak, respectively. Variables in bold represent measured sulfate $\left(\mathrm{SO}_{4}^{-}\right)$concentrations and non-bold variables $\mathrm{SO}_{2}$ transport. The acronym OP stands for occult precipitation.

\begin{tabular}{lrrrr}
\hline & $\begin{array}{r}\text { Biomass-burning } \\
\left(\mathrm{GFED} \mathrm{SO}_{2}\right)\end{array}$ & $\begin{array}{r}\text { Regional volcanic and } \\
\text { strong anthropogenic } \\
\left(\mathrm{OMI} \mathrm{SO}_{2}\right)\end{array}$ & $\begin{array}{r}\text { Volcanic } \\
\left(\text { Aerocom } \mathrm{SO}_{2}\right)\end{array}$ & $\begin{array}{r}\text { Anthropogenic } \\
\left(\mathrm{EDGAR} \mathrm{SO}_{2}\right)\end{array}$ \\
\hline OP SO$_{4}^{-}$(El Tiro) & $0.43^{* * *}$ & $0.40^{* *}$ & 0.18 & 0.19 \\
Rain SO$_{4}^{-}$(El Tiro) & 0.08 & $0.33^{*}$ & $0.39^{* *}$ & $0.46^{* * *}$ \\
OP SO$_{4}^{-}$(C. del Consuelo) & 0.27 & $0.43^{* *}$ & $0.52^{* * *}$ & $0.37^{* *}$ \\
Rain SO$_{4}^{-}$(C. del Consuelo) & 0.21 & 0.09 & 0.12 & 0.14 \\
\hline
\end{tabular}

Note: ${ }^{* * *} p<0.001,{ }^{* *} p<0.01,{ }^{*} p<0.05$.

Between March and May of 2005 to 2007, small peaks in the biomass-burning $\mathrm{SO}_{2}$ transport time series can be seen which very likely correspond with the emissions of the Venezuelan savanna's biomass-burning season as observed by Hamburger et al. (2013). Apparently, this biomassburning emission source has no significant resonance in the deposition at our study site. In 2008 and 2009 the peaks almost disappear, again coinciding with the anomalous biomass-burning season these 2 years (Torres et al., 2010).

\subsection{Factor analysis}

Table 4 presents the results from factor analysis applied to observational and modeled data. A main outcome is that the three first factors explain more than $80 \%$ of the variance for both El Tiro and Cerro del Consuelo MSs.

For the Cerro del Consuelo MS, the eigenvectors show that biomass-burning $\mathrm{SO}_{2}$ transport (GFED) was related to the sulfate concentrations in rain since both were loaded to the factors 2 and 3 . The rest were more closely related to sulfate concentrations in OP, with loadings to factors 1,4 , and 5. The commonalities also show that factor 2 was dominated by biomass-burning $\mathrm{SO}_{2}$ (GFED) and rain sulfate concentrations. Factor 1 shows important loadings of OP sulfate concentrations and $\mathrm{SO}_{2}$ transport from all other source data sets (OMI, Aerocom, and EDGAR).

At the El Tiro MS, the relationship was inverse; biomassburning $\mathrm{SO}_{2}$ modeled transport and $\mathrm{OP}$ sulfate concentrations were more closely related, both of them contributing to factor 2. Loadings from rain sulfate concentrations and all other source data sets contributed to factor 1 , and therefore they lay close in the multidimensional space. This is stressed by the commonalities, where both the variance of OP sulfate concentrations and biomass-burning $\mathrm{SO}_{2}$ transport contributed mainly to factor 2 , and rain sulfate concentrations and the $\mathrm{SO}_{2}$ transport from the rest of emission sources to factor 1 .

\section{Discussion}

In this study, we concerned ourselves with the identification of important natural and anthropogenic sources contributing to atmospheric sulfate deposition in the tropical mountain forests of southeastern Ecuador. Special attention was given to the contribution of natural volcanic emissions, given that the study site is located in a region with a very high density of active volcanoes (Carn et al., 2008).

Based on fire pixels, emission inventories, and backtrajectories, several previous studies (Fabian et al., 2005, 2009; Rollenbeck, 2010; Rollenbeck et al., 2006) have pinpointed biomass burning as the principal source of atmospheric sulfate. These did not use, however, either data on explosive emissions or passive degassing, which represents a considerable part of the total volcanic emissions (Carn et al., 2008). Because of this fact, we have concluded that the contribution of volcanoes to the sulfate deposition in the area may have being underestimated.

Contrary to what we expected, we found that, quantitatively, volcanic emission sources did not play a substantial role, even if they were more important than anthropogenic emissions. Biomass-burning sources were indeed substantially dominant for two reasons: first, because easterlies are strong and constant, which is translated into preponderant air mass transport from the east (Bendix et al., 2008b), where the main biomass-burning region is located; second, because biomass-burning emissions in the Brazilian Amazon are strong and the burns cover a very large surface area (Giglio et al., 2010; Prins and Menzel, 1992), making it more likely for the emissions to be advected. Transport from the north and west occurred only for short periods and the sources of $\mathrm{SO}_{2}$ did not cover such a big surface as biomass burning in the Brazilian Amazon did (Fig. 4c). However, no single emission sources explained the variability in the deposition, rather it was the sum of individual contributions, always depending on the type of precipitation and the topographic features of the site where samples where gathered. 
Table 4. Eigenvectors and commonalities from factor analysis with varimax rotation, where (a) shows the results of the data aggregated according to Cerro del Consuelo meteorological station (MS) sample collection dates and (b) those for El Tiro MS.

\begin{tabular}{|c|c|c|c|c|c|c|}
\hline \multirow[t]{2}{*}{ (a) } & \multicolumn{6}{|c|}{ Eigenvectors } \\
\hline & Factor 1 & Factor 2 & Factor 3 & Factor 4 & Factor 5 & Factor 6 \\
\hline GFED $\mathrm{SO}_{2}$ & 0.14 & 0.61 & 0.69 & 0.12 & 0.28 & 0.12 \\
\hline $\mathrm{OMI} \mathrm{SO}_{2}$ & -0.48 & -0.08 & 0.27 & 0.65 & -0.40 & -0.31 \\
\hline Aerocom $\mathrm{SO}_{2}$ & -0.51 & -0.07 & 0.16 & -0.44 & 0.46 & -0.55 \\
\hline EDGAR $\mathrm{SO}_{2}$ & -0.53 & -0.21 & -0.02 & 0.17 & 0.39 & 0.70 \\
\hline Cerro del C. OP SO & -0.42 & 0.41 & -0.005 & -0.5 & -0.58 & 0.25 \\
\hline \multirow[t]{2}{*}{ Cerro del C. rain $\mathrm{SO}_{4}^{-}$} & -0.16 & 0.63 & -0.64 & 0.30 & 0.23 & -0.16 \\
\hline & \multicolumn{6}{|c|}{ Commonalities } \\
\hline GFED $\mathrm{SO}_{2}$ & $6 \%$ & $55 \%$ & $35 \%$ & $1 \%$ & $3 \%$ & $0 \%$ \\
\hline $\mathrm{OMI} \mathrm{SO}_{2}$ & $66 \%$ & $1 \%$ & $5 \%$ & $19 \%$ & $6 \%$ & $1 \%$ \\
\hline Aerocom $\mathrm{SO}_{2}$ & $76 \%$ & $1 \%$ & $2 \%$ & $9 \%$ & $8 \%$ & $5 \%$ \\
\hline EDGAR $\mathrm{SO}_{2}$ & $79 \%$ & $6 \%$ & $0 \%$ & $1 \%$ & $6 \%$ & $8 \%$ \\
\hline Cerro del C. OP SO & $50 \%$ & $25 \%$ & $0 \%$ & $11 \%$ & $13 \%$ & $1 \%$ \\
\hline Cerro del C. rain $\mathrm{SO}_{4}^{-}$ & $7 \%$ & $56 \%$ & $30 \%$ & $4 \%$ & $2 \%$ & $0 \%$ \\
\hline (b) & \multicolumn{6}{|c|}{ Eigenvectors } \\
\hline GFED $\mathrm{SO}_{2}$ & 0.04 & 0.69 & 0.24 & 0.51 & 0.45 & 0.01 \\
\hline $\mathrm{OMI} \mathrm{SO}_{2}$ & -0.47 & 0.1 & -0.68 & 0 & 0.24 & 0.50 \\
\hline Aerocom $\mathrm{SO}_{2}$ & -0.47 & -0.25 & 0.25 & 0.64 & -0.46 & 0.17 \\
\hline EDGAR $\mathrm{SO}_{2}$ & -0.5 & -0.33 & 0.02 & 0.03 & 0.52 & 0.60 \\
\hline El Tiro OP SO ${ }_{4}^{-}$ & -0.34 & 0.56 & -0.22 & -0.18 & -0.5 & -0.48 \\
\hline \multirow[t]{2}{*}{$\mathrm{El}$ Tiro rain $\mathrm{SO}_{4}^{-}$} & -0.44 & 0.16 & 0.61 & 0.08 & -0.53 & 0.34 \\
\hline & \multicolumn{6}{|c|}{ Commonalities } \\
\hline GFED $\mathrm{SO}_{2}$ & $0 \%$ & $75 \%$ & $4 \%$ & $14 \%$ & $7 \%$ & $0 \%$ \\
\hline $\mathrm{OMI} \mathrm{SO}_{2}$ & $56 \%$ & $1 \%$ & $34 \%$ & $0 \%$ & $2 \%$ & $7 \%$ \\
\hline Aerocom $\mathrm{SO}_{2}$ & $56 \%$ & $10 \%$ & $5 \%$ & $22 \%$ & $7 \%$ & $1 \%$ \\
\hline EDGAR $\mathrm{SO}_{2}$ & $64 \%$ & $17 \%$ & $0 \%$ & $0 \%$ & $9 \%$ & $10 \%$ \\
\hline El Tiro OP SO & $30 \%$ & $50 \%$ & $4 \%$ & $2 \%$ & $8 \%$ & $6 \%$ \\
\hline $\mathrm{El}$ Tiro rain $\mathrm{SO}_{4}^{-}$ & $50 \%$ & $4 \%$ & $28 \%$ & $15 \%$ & $0 \%$ & $3 \%$ \\
\hline
\end{tabular}

The correlation analysis of $\mathrm{SO}_{2}$ transport and sulfate concentrations resulted in some significant but not so strong correlations. Furthermore, the comparison of time series revealed that no single transport curve completely matches either OP or rain concentrations. The different source-related transport curves coincided only in specific time periods with the concentration curves, producing OP and/or rain deposition depending on the location of the MS. This is clarified in the following subsections and a graphical interpretation is given in Fig. 6.

\subsection{Easterly transport}

The correlation between El Tiro MS and biomass-burning transport was significant but weak only for OP samples. This relationship was supported by factor analysis.

In the period from August to October, the tropical easterlies still blow strongly and persistently and overlap with the occurrence of the biomass-burning season in the Amazon basin. Sulfur emissions, primarily from the Brazilian Amazon, are transported towards the west until they encounter the first foothills and cordilleras of the Andean mountain range, where intense scavenging of pollutants takes place. The connection to the emissions in the Amazon basin is mainly noticed in OP sulfate concentrations from El Tiro MS (dark grey bars in Fig. 5a, e). Here, concentration peaks coincide with $\mathrm{SO}_{2}$ transport. Biomass-burning emissions have a mean low injection height into the atmosphere (max. $3 \mathrm{~km}$, but only a very thin haze, while the main heating at $850 \mathrm{hPa}$ has a mean injection height of $1.5 \mathrm{~km}$, Davidi et al., 2009), which means that the pollution is transported in the lower valley upwards with the up-valley winds and hits the fog collectors at El Tiro (2660 $\mathrm{m}$ a.s.l.).

The same easterly air masses hit the mountain on top of which the Cerro del Consuelo MS is located, and are adiabatically uplifted producing intense rainfall and OP mainly 


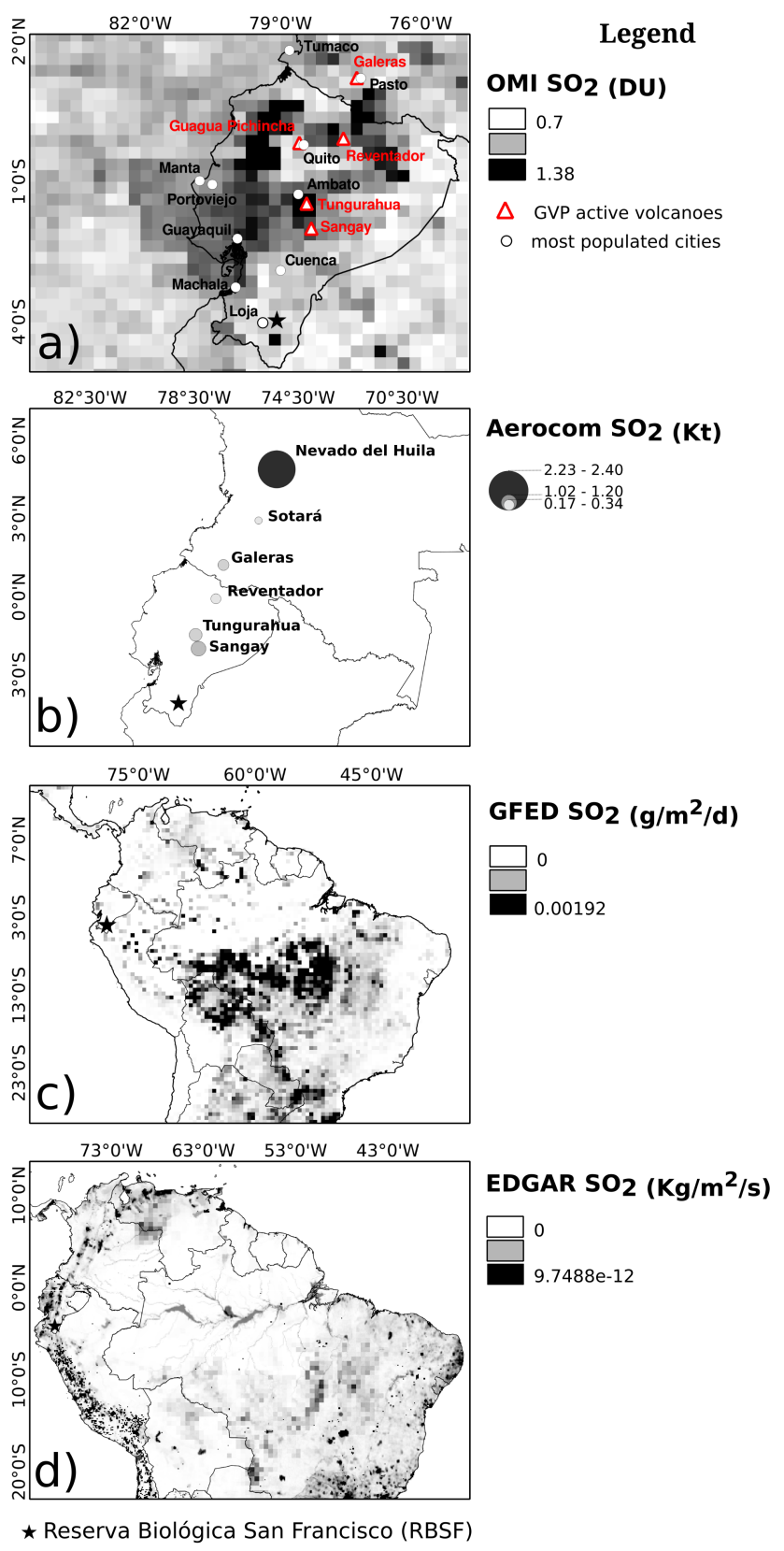

Figure 4. Average 2005-2009 source-dependent emission maps for (a) volcanic and strong anthropogenic regional emissions, (b) volcanic eruptive and passive degassing, (c) biomass-burning, and (d) anthropogenic emissions.

windward but also on the summit. The fog collector is not located directly on the windward hillside, exposed to ascending air masses, so water with high ion loads is apparently mostly collected by the rain gauges, as shown by time series and factor analysis. However, measurements from fog collectors and rain gauges overlap here more frequently than at El Tiro, making the separation between rain and OP more difficult. The result is that the rain and OP differentiation is fuzzy, which blurs the correlations between concentrations and transport. Hence, the biomass-burning signal is relatively low here.

\subsection{Northerly and westerly transport}

Volcanic and anthropogenic transport were significantly correlated to sulfate concentrations from El Tiro MS rain samples and OP samples from Cerro del Consuelo MS. The same was also reflected in the results of the factor analysis.

Between October and January, as northerlies set in, the volcanic $\mathrm{SO}_{2}$ transport time series coincide with those of sulfate concentrations from the MSs, especially regarding sulfate in rain, from El Tiro MS, and in OP from Cerro del Consuelo MS. The greater recurrence of coincidences with the rain time series at El Tiro MS is explained by its location at a mountain pass which links the eastern slopes and the interAndean valley of Loja. The two parallel east-to-west mountain ranges mark the boundaries of the San Francisco Valley. As already mentioned (Sect. 5.1), they shape the wind field, leading advected polluted air masses to come from the east or west, like biomass-burning transport, to impact the vegetation and the east-west oriented fog collectors on the mountain pass. Clouds advected from the north and northwest (likely charged with $\mathrm{SO}_{2}$ ions) are partially blocked by the delimiting mountain range to the north. Hence, only rain gauges can collect sulfate scavenged from these clouds as rain drops traverse the atmosphere on their way to the ground.

Between 20 and $50 \%$ of wind trajectories reach the RBSF from the north, passing over areas of active volcanoes. Volcanoes in the Andes lie at altitudes that in most cases exceed $4000 \mathrm{~m}$ a.s.l., so even emissions from degassing can contaminate high clouds in the lower troposphere (Diehl et al., 2012; Stuefer et al., 2013). During these months there is also an incremental increase in the transport of anthropogenic $\mathrm{SO}_{2}$, most likely in response to air masses passing over emission sources from Ecuadorian and possibly Colombian cities. Anthropogenic sources in the Andes north of the RBSF also lie at high altitudes and, as recent studies have reported for Europe, this type of emissions can also reach higher atmospheric levels than previously assumed (Bieser et al., 2011). This would make anthropogenic plumes from Ecuadorian big cities in the Andes likely to reach higher clouds in the atmosphere as well. Therefore, northerly air masses charged with volcanic sulfate particles, and to a lesser extent anthropogenic particles, directly strike the mountain where the Cerro del Consuelo fog collector is located, on the windward (north-facing slopes) side. Occult precipitation water is here a major part of precipitation ( $41 \%$ of rainfall; Bendix et al., 2008b). In addition, it is located at $3200 \mathrm{~m}$ a.s.l., probably more exposed to pollutants transported through higher atmospheric levels than El Tiro MS. Multicollinearity found between volcanic, anthropogenic, and regional (Ecuadorian) transport data sets reinforces this hypothesis (Table 2). 
EI Tiro
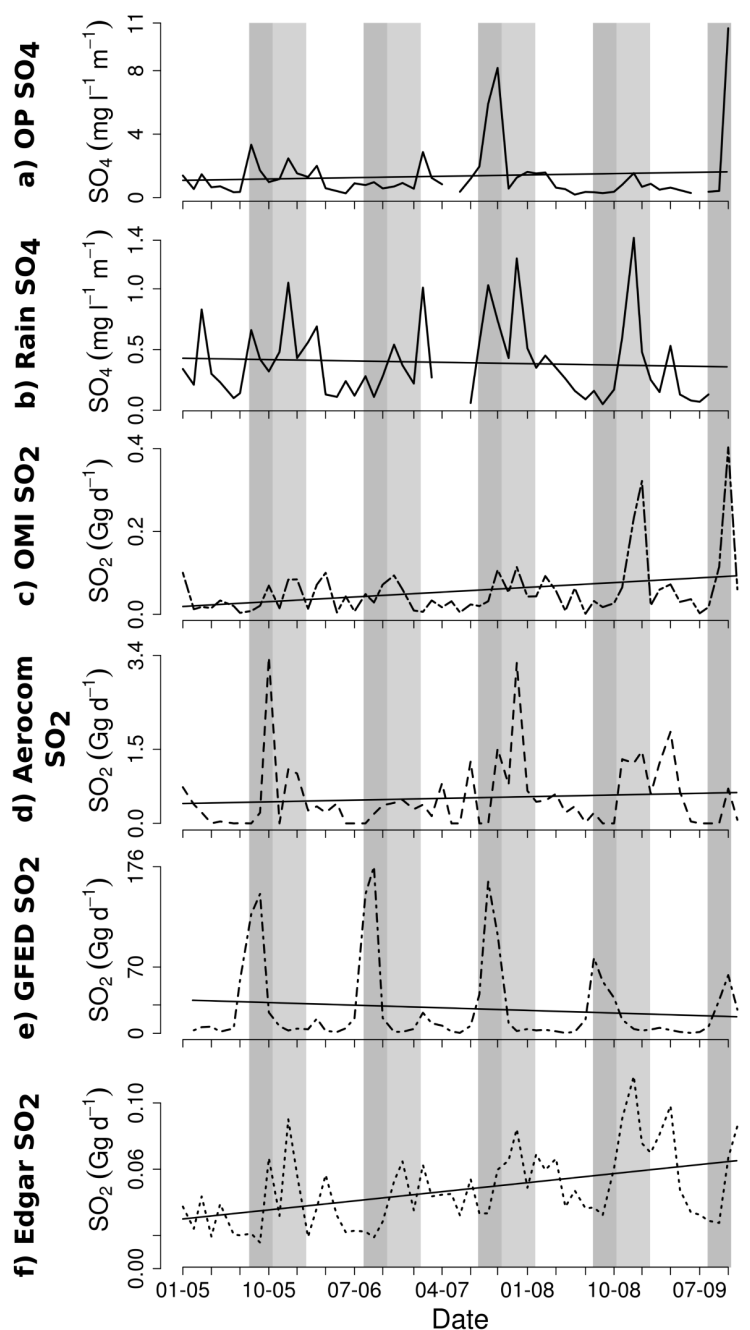

\section{Cerro del Consuelo}

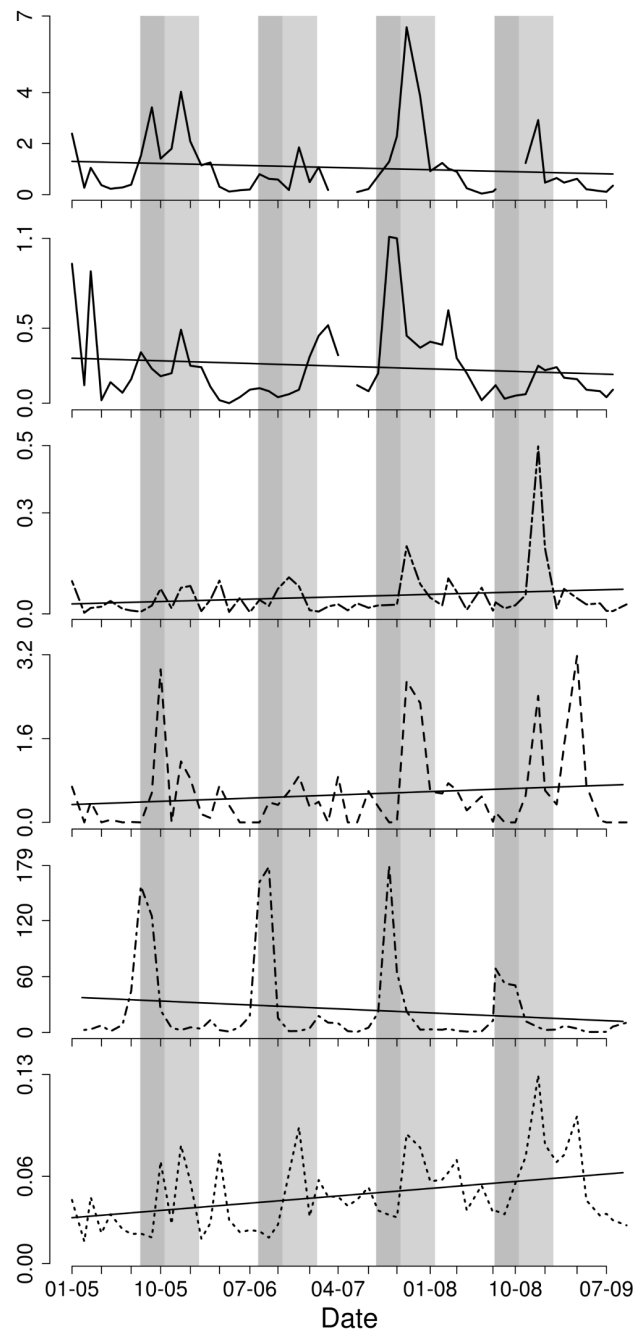

Figure 5. Time series comparing $\mathrm{SO}_{2}$ transport from (c) volcanic and strong anthropogenic regional emissions (OMI), (d) volcanic emissions (Aerocom), (e) biomass-burning emissions (GFED), and (f) anthropogenic emissions (EDGAR), to measured sulfate concentrations in (a) occult precipitation (OP) and (b) rainwater from Cerro del Consuelo (right panel) and El Tiro (left panel) meteorological stations (MSs). The black straight line represents the line of best fit. Dark grey bars depict the Amazonian biomass-burning season (easterly wind direction) and light grey bars, the shift of the incoming air masses towards a northerly/northwesterly/westerly direction. Note the different scaling of the $y$ axes.

\section{Conclusions}

We conclude that biomass-burning sources dominate the sulfate deposition as a result of strong and persistent easterly sulfate transport of emissions from large burned areas of Amazon forests and from anthropogenic sources replacing the forests (pastures and croplands). These take place during the main Amazon biomass-burning season between August and October. Between October and December, the main wind direction shifts to the north and west, transporting volcanic and anthropogenic sulfate to our study site. The transport from these sources is, nonetheless, much less compared to biomass burning.
We found two different deposition regimes at the evaluated topographic sites. The up-valley mountain pass El Tiro is located on the eastern side of the ridge and is characterized by a more advective environment with dominating OP deposition from low tropospheric fire-polluted air masses from the Amazon lowlands. Sulfate from volcanic and anthropogenic emissions are episodically transported through a higher atmospheric level from the north and, as there is no cloud immersion during these wind directions, sulfate can be only deposited by rain.

At the highest mountain crest of the study area, Cerro del Consuelo, the situation is less homogeneous and less clear. Deposition was dominated by OP until 2007, when it started 


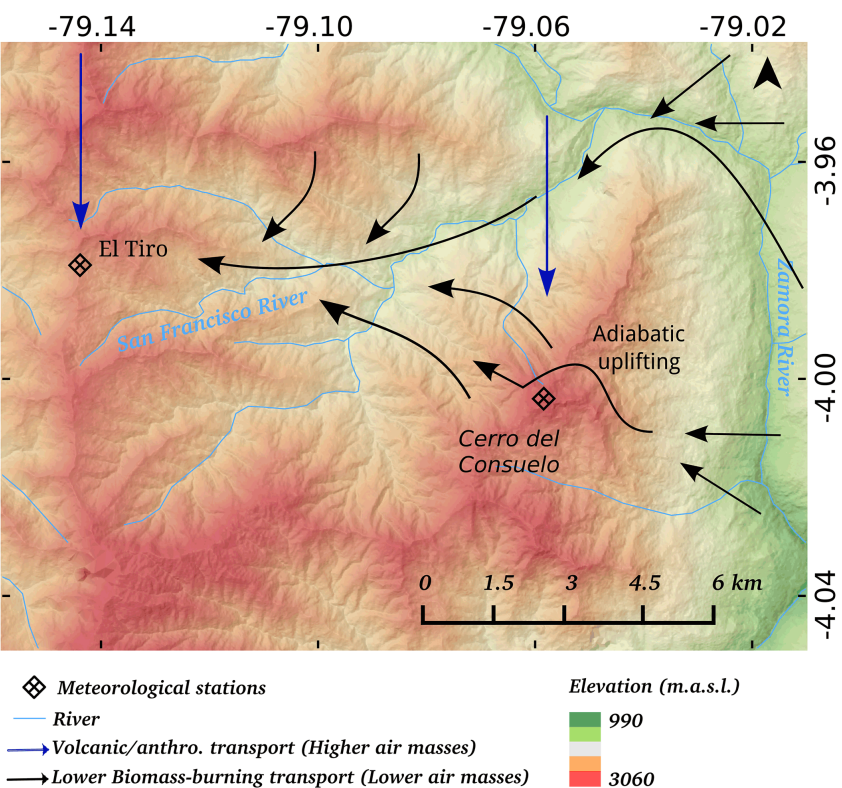

Figure 6. Representation of the deposition regimes observed in the study area. The blue arrows represent volcanic and anthropogenic transport from the north and northwest creating rain deposition at El Tiro meteorological station (MS) and occult precipitation (OP) deposition at Cerro del Consuelo MS. The black arrows represent biomass-burning transport from the east causing OP deposition at El Tiro MS and mainly rain deposition at Cerro del Consuelo MS.

to be dominated by rain. Sulfate deposition by OP is likely linked to volcanic and anthropogenic sources in the north as a consequence of its higher location and its orientation. The higher atmospheric transport reaches Cerro del Consuelo MS from all wind directions and thus contaminates the cloud fog, resulting in OP deposition. According to the crosscorrelation results, biomass burning has no significant relationship with this site's deposition. The overlapping of rain gauge and fog collector measurements made the differentiation of deposition types difficult. However, time series and factor analyses show a likely contribution of human-induced fires in the lowlands to sulfate deposition by rain at Cerro del Consuelo MS. The higher conductivity of the rain samples point to the likely higher contamination of the rain samples as well.

In general, this study revealed that even if volcanic emission are proximate and numerous, they do not dominate the sulfate deposition at the RBSF. The shape and size of the sources, as well as the consistency of the winds, are important parameters that determined the dominance of biomassburning emissions in the deposition at the study site. However, the importance of topography is also stressed as important parameter in determining the type and quantity of deposition in areas with complex terrain.
Author contributions. J. Bendix, R. Rollenbeck, and S. Makowski Giannoni designed the experiments and S. Makowski Giannoni carried them out. R. Rollenbeck developed the trajectory model code and S. Makowski Giannoni performed the simulations. S. Makowski Giannoni and K. Trachte collected, processed, and adapted the satellite data and emission inventories to the format requested for model runs. S. Makowski Giannoni analyzed the data and prepared the manuscript with contributions from all co-authors.

Acknowledgements. We thank the German Academic Exchange Service (DAAD) for funding the $\mathrm{PhD}$ thesis of S. Makowski Giannoni (Ref. no. A/08/98222) and the German Research Foundation (DFG) for the funding of the work in the scope of the Research Unit RU816 (funding no. BE 1780/15-1). We are grateful to Giulia F. Curatola Fernández, Lukas Lehnert, Nicolas Caspari, and Maik Dobermann for their valuable help. We also thank the foundation Nature \& Culture International (NCI) Loja and San Diego for logistic support. We finally thank L. Zhang, and the two anonymous referees for their valuable comments and corrections.

Edited by: L. Zhang

\section{References}

Andreae, M. O., Rosenfeld, D., Artaxo, P., Costa, A. A., Frank, G. P., Longo, K. M., and Silva-Dias, M. A. F.: Smoking rain clouds over the Amazon, Science, 303, 1337-1342, doi:10.1126/science.1092779, 2004.

Beck, E., Bendix, J., Kottke, I., Makeschin, F., and Mosandl, R., (Eds.): Gradients in a tropical mountain ecosystem of Ecuador, Springer Berlin/Heidelberg, Berlin, Germany, 1-527, 2008.

Beiderwieden, E., Wrzesinsky, T., and Klemm, O.: Chemical characterization of fog and rain water collected at the eastern Andes cordillera, Hydrol. Earth Syst. Sci., 9, 185-191, doi:10.5194/hess-9-185-2005, 2005.

Bendix, J. and Beck, E.: Spatial aspects of ecosystem research in a biodiversity hot spot of southern Ecuador - an introduction, Erdkunde, 63, 305-308, doi:10.3112/erdkunde.2009.04.01, 2009.

Bendix, J., Rollenbeck, R., Göttlicher, D., and Cermak, J.: Cloud occurrence and cloud properties in Ecuador, Clim. Res., 30, 133147, doi:10.3354/cr030133, 2006a.

Bendix, J., Rollenbeck, R., and Reudenbach, C.: Diurnal patterns of rainfall in a tropical Andean valley of southern Ecuador as seen by a vertically pointing K-band Doppler radar, Int. J. Climatol., 26, 829-846, doi:10.1002/joc.1267, 2006b.

Bendix, J., Rollenbeck, R., Göttlicher, D., Nauß, T., and Fabian, P.: Seasonality and diurnal pattern of very low clouds in a deeply incised valley of the eastern tropical Andes (South Ecuador) as observed by a cost-effective WebCam system, Meteorol. Appl., 15, 281-291, doi:10.1002/met.72, 2008a.

Bendix, J., Rollenbeck, R., Richter, M., Fabian, P., and Emck, P.: Climate, in Gradients in a Tropical Mountain Ecosystem of Ecuador, edited by E. Beck, J. Bendix, I. Kottke, F. Makeschin, and R. Mosandl, Springer Berlin/Heidelberg, 198, 63-74, doi:10.1007/978-3-540-73526-7_8, 2008b.

Bendix, J., Beck, E., Bräuning, A., Makeschin, F., Mosandl, R., Scheu, S., and Wilcke, W., (Eds.): Ecosystem Services, Biodiver- 
sity and Environmental Change in a Tropical Mountain Ecosystem of South Ecuador, Springer Berlin/Heidelberg, Berlin, Germany, 1-440, 2013.

Bieser, J., Aulinger, A., Matthias, V., Quante, M., and Denier van der Gon, H. C.: Vertical emission profiles for Europe based on plume rise calculations, Environ. Pollut., 159, 2935-2946, doi:10.1016/j.envpol.2011.04.030, 2011.

Boy, J., Rollenbeck, R., Valarezo, C., and Wilcke, W.: Amazonian biomass burning-derived acid and nutrient deposition in the north Andean montane forest of Ecuador, Global Biogeochem. Cy., 22, GB4011, doi:10.1029/2007GB003158, 2008.

Carn, S. A., Krotkov, N. A., Yang, K., Hoff, R. M., Prata, A. J., Krueger, A. J., Loughlin, S. C., and Levelt, P. F.: Extended observations of volcanic $\mathrm{SO}_{2}$ and sulfate aerosol in the stratosphere, Atmos. Chem. Phys. Discuss., 7, 2857-2871, doi:10.5194/acpd7-2857-2007, 2007.

Carn, S. A., Krueger, A. J., Arellano, S., Krotkov, N. A., and Yang, K.: Daily monitoring of Ecuadorian volcanic degassing from space, J. Volcanol. Geotherm. Res., 176, 141-150, doi:10.1016/j.jvolgeores.2008.01.029, 2008.

Crutzen, P. J. and Andreae, M. O.: Biomass burning in the tropics: impact on atmospheric chemistry and biogeochemical cycles, Science, 250, 1669-1678, doi:10.1126/science.250.4988.1669, 1990.

Curatola Fernández, G. F., Silva, B., Gawlik, J., Thies, B., and Bendix, J.: Bracken fern frond status classification in the Andes of southern Ecuador: combining multispectral satellite data and field spectroscopy, Int. J. Remote Sens., 34, 7020-7037, doi:10.1080/01431161.2013.813091, 2013.

Davidi, A., Koren, I., and Remer, L.: Direct measurements of the effect of biomass burning over the Amazon on the atmospheric temperature profile, Atmos. Chem. Phys., 9, 8211-8221, doi:10.5194/acp-9-8211-2009, 2009.

Delmelle, P., Stix, J., Bourque, C. P. A., Baxter, P. J., GarciaAlvarez, J., and Barquero, J.: Dry deposition and heavy acid loading in the vicinity of Masaya volcano, a major sulfur and chlorine source in Nicaragua, Environ. Sci. Technol., 35, 12891293, doi:10.1021/es000153m, 2001.

Delmelle, P., Stix, J., Baxter, P. J., and Garcia-Alvarez, J.: Atmospheric dispersion, environmental effects and potential health hazard associated with the low-altitude gas plume of Masaya volcano, Nicaragua, Bull. Volcanol., 64, 423-434, doi:10.1007/s00445-002-0221-6, 2002.

Dentener, F., Drevet, J., Lamarque, J. F., Bey, I., Eickhout, B., Fiore, A. M., Hauglustaine, D., Horowitz, L. W., Krol, M., Kulshrestha, U. C., Lawrence, M., Galy-Lacaux, C., Rast, S., Shindell, D., Stevenson, D., Van Noije, T., Atherton, C., Bell, N., Bergman, D., Butler, T., Cofala, J., Collins, B., Doherty, R., Ellingsen, K., Galloway, J., Gauss, M., Montanaro, V., Müller, J. F., Pitari, G., Rodriguez, J., Sanderson, M., Solmon, F., Strahan, S., Schultz, M., Sudo, K., Szopa, S., and Wild, O.: Nitrogen and sulfur deposition on regional and global scales: A multimodel evaluation, Global Biogeochem. Cy., 20, GB4003, doi:10.1029/2005GB002672, 2006.

Diehl, T., Heil, A., Chin, M., Pan, X., Streets, D., Schultz, M., and Kinne, S.: Anthropogenic, biomass burning, and volcanic emissions of black carbon, organic carbon, and $\mathrm{SO}_{2}$ from 1980 to 2010 for hindcast model experiments, Atmos. Chem. Phys.
Discuss., 12, 24895-24954, doi:10.5194/acpd-12-24895-2012, 2012.

Eklund, T., McDowell, W., and Pringle, C.: Seasonal variation of tropical precipitation chemistry: La Selva, Costa Rica, Atmos. Environ., 31, 3903-3910, 1997.

Elser, J. J., Bracken, M. E. S., Cleland, E. E., Gruner, D. S., Harpole, W. S., Hillebrand, H., Ngai, J. T., Seabloom, E. W., Shurin, J. B., and Smith, J. E.: Global analysis of nitrogen and phosphorus limitation of primary producers in freshwater, marine and terrestrial ecosystems, Ecol. Lett., 10, 1135-42, doi:10.1111/j.14610248.2007.01113.x, 2007.

Emck, P.: A climatology of South Ecuador, University of Erlangen, available at: http://www.opus.ub.uni-erlangen.de/opus/volltexte/ 2007/656/ (last access: 15 August 2012), 2007.

Fabian, P., Kohlpaintner, M., and Rollenbeck, R.: Biomass burning in the Amazon-fertilizer for the mountaineous rain forest in Ecuador, Environ. Sci. Pollut. Res., 12, 290-296, doi:10.1065/espr2005.07.272, 2005.

Fabian, P., Rollenbeck, R., Spichtinger, N., Brothers, L., Dominguez, G., and Thiemens, M.: Sahara dust, ocean spray, volcanoes, biomass burning: pathways of nutrients into Andean rainforests, Adv. Geosci., 22, 85-94, doi:10.5194/adgeo-22-852009, 2009.

Giglio, L., Randerson, J. T., van der Werf, G. R., Kasibhatla, P. S., Collatz, G. J., Morton, D. C., and DeFries, R. S.: Assessing variability and long-term trends in burned area by merging multiple satellite fire products, Biogeosciences, 7, 1171-1186, doi:10.5194/bg-7-1171-2010, 2010.

Gordon, C., Herrera, R., and Hutchinson, T.: Studies of fog events at two cloud forests near Caracas, Venezuela-II, Chemistry of fog, Atmos. Environ., 28, 323-337, 1994.

Graf, H.-F., Feichter, J., and Langmann, B.: Volcanic sulfur emissions: Estimates of source strength and its contribution to the global sulfate distribution, J. Geophys. Res., 102, 10727, doi:10.1029/96JD03265, 1997.

Greaver, T. L., Sullivan, T. J., Herrick, J. D., Barber, M. C., Baron, J. S., Cosby, B. J., Deerhake, M. E., Dennis, R. L., Dubois, J.-J. B., Goodale, C. L., Herlihy, A. T., Lawrence, G. B., Liu, L., Lynch, J. A., and Novak, K. J.: Ecological effects of nitrogen and sulfur air pollution in the US: what do we know?, Front. Ecol. Environ., 10, 365-372, doi:10.1890/110049, 2012.

Hamburger, T., Matisāns, M., Tunved, P., Ström, J., Calderon, S., Hoffmann, P., Hochschild, G., Gross, J., Schmeissner, T., Wiedensohler, A., and Krejci, R.: Long-term in situ observations of biomass burning aerosol at a high altitude station in Venezuela - sources, impacts and interannual variability, Atmos. Chem. Phys., 13, 9837-9853, doi:10.5194/acp-13-9837-2013, 2013.

Hansen, J., Ruedy, R., Sato, M., and Lo, K.: Global surface temperature change, Rev. Geophys., 48, RG4004, doi:10.1029/2010RG000345, 2010.

Hansen, M. C., Potapov, P. V., Moore, R., Hancher, M., Turubanova, S. A., Tyukavina, A., Thau, D., Stehman, S. V, Goetz, S. J., Loveland, T. R., Kommareddy, A., Egorov, A., Chini, L., Justice, C. O., and Townshend, J. R. G.: High-resolution global maps of 21st-century forest cover change, Science, 342, 850853, doi:10.1126/science.1244693, 2013.

Hartig, K. and Beck, E.: The bracken fern (Pteridium arachnoideum (Kaulf.) Maxon) dilemma in the Andes of Southern Ecuador, Ecotropica, 9, 3-13, 2003. 
Homeier, J., Hertel, D., Camenzind, T., Cumbicus, N. L., Maraun, M., Martinson, G. O., Poma, L. N., Rillig, M. C., Sandmann, D., Scheu, S., Veldkamp, E., Wilcke, W., Wullaert, H., Leuschner, C.: Tropical Andean forests are highly susceptible to nutrient inputs - rapid effects of experimental $\mathrm{N}$ and $\mathrm{P}$ addition to an Ecuadorian montane forest, PLoS ONE, 7, E47128, doi:10.1371/journal.pone.0047128, 2012.

INEC: Fascículo provincial Zamora Chinchipe, Result. del censo población y vivienda, available at: http://www.ecuadorencifras.gob.ec/wp-content/descargas/ Manu-lateral/Resultados-provinciales/, 2010.

Janssens-Maenhout, G., Dentener, F., Aardenne, J. van, Monni, S., Pagliari, V., Orlandini, L., Klimont, Z., Kurokawa, J., Akimoto, H., Ohara, T., Wankmüller, R., Battye, B., Grano, D., Zuber, A., and Keating, T.: EDGAR-HTAP: a harmonized gridded air pollution emission dataset based on national inventories, Ispra, Italy, 2012.

Kuylenstierna, J. C. I., Rodhe, H., Cinderby, S., and Hicks, K.: Acidification in developing countries: ecosystem sensitivity and the critical load approach on a global scale, AMBIO A. J. Hum. Environ., 30, 20-28, doi:10.1579/0044-7447-30.1.20, 2001.

Langmann, B. and Graf, H. F.: Indonesian smoke aerosols from peat fires and the contribution from volcanic sulfur emissions, Geophys. Res. Lett., 30, 1547, doi:10.1029/2002GL016646, 2003.

Lee, C., Martin, R. V., van Donkelaar, A., Lee, H., Dickerson, R. R., Hains, J. C., Krotkov, N., Richter, A., Vinnikov, K., and Schwab, J. J.: $\mathrm{SO}_{2}$ emissions and lifetimes: estimates from inverse modeling using in situ and global, space-based (SCIAMACHY and OMI) observations, J. Geophys. Res., 116, D06304, doi:10.1029/2010JD014758, 2011.

Ljung, K., Maley, F., Cook, A., and Weinstein, P.: Acid sulfate soils and human health-a millennium ecosystem assessment, Environ. Int., 35, 1234-1242, doi:10.1016/j.envint.2009.07.002, 2009.

Makowski Giannoni, S., Rollenbeck, R., Fabian, P., and Bendix, J.: Complex topography influences atmospheric nitrate deposition in a neotropical mountain rainforest, Atmos. Environ., 79, 385394, doi:10.1016/j.atmosenv.2013.06.023, 2013.

Menz, F. C. and Seip, H. M.: Acid rain in Europe and the United States: an update, Environ. Sci. Policy, 7, 253-265, doi:10.1016/j.envsci.2004.05.005, 2004.

Morales, J., Bifano, C., and Escalona, A.: Atmospheric deposition of $\mathrm{SO}_{4}-\mathrm{S}$ and $\left(\mathrm{NH}_{4}+\mathrm{NO}_{3}\right)-\mathrm{N}$ at two rural sites in the Western Maracaibo Lake Basin, Venezuela, Atmos. Environ., 32, 30513058, 1998.

Mu, M., Randerson, J. T., Van der Werf, G. R., Giglio, L., Kasibhatla, P., Morton, D., Collatz, G. J., DeFries, R. S., Hyer, E. J., Prins, E. M., Griffith, D. W. T., Wunch, D., Toon, G. C., Sherlock, V., and Wennberg, P. O.: Daily and 3-hourly variability in global fire emissions and consequences for atmospheric model predictions of carbon monoxide, J. Geophys. Res., 116, D24303,doi:10.1029/2011JD016245, 2011.

Pauliquevis, T., Lara, L. L., Antunes, M. L., and Artaxo, P.: Aerosol and precipitation chemistry measurements in a remote site in Central Amazonia: the role of biogenic contribution, Atmos. Chem. Phys., 12, 4987-5015, doi:10.5194/acp-12-4987-2012, 2012.

Pfeffer, M. A., Langmann, B., and Graf, H.-F.: Atmospheric transport and deposition of Indonesian volcanic emissions, At- mos. Chem. Phys., 6, 2525-2537, doi:10.5194/acp-6-2525-2006, 2006.

Phoenix, G. K., Hicks, K. W., Cinderby, S., Kuylenstierna, J. C. I., Stock, W. D., Dentener, F. J., Giller, K. E., Austin, A. T., Lefroy, R. D. B., Gimeno, B. S., Ashmore, M. R., and Ineson, P.: Atmospheric nitrogen deposition in world biodiversity hotspots: the need for a greater global perspective in assessing $\mathrm{N}$ deposition impacts, Glob. Chang. Biol., 12, 470-476, doi:10.1111/j.13652486.2006.01104.x, 2006.

Prins, E. M. and Menzel, W. P.: Geostationary satellite detection of biomass burning in South America, Int. J. Remote Sens., 13, 2783-2799, doi:10.1080/01431169208904081, 1992.

Rissler, J., Vestin, A., Swietlicki, E., Fisch, G., Zhou, J., Artaxo, P., and Andreae, M. O.: Size distribution and hygroscopic properties of aerosol particles from dry-season biomass burning in Amazonia, Atmos. Chem. Phys., 6, 471-491, doi:10.5194/acp6-471-2006, 2006.

Rodrigues-Ramos, A., Prado do Nascimento, E., and Oliveira, M.: Temporada de incêndios florestais no Brasil em 2010: análise de série histórica de 2005 a 2010 e as influências das chuvas e do desmatamento na quantidade dos focos de calor, in Simpósio Brasileiro de Sensoriamento Remoto, 7902-7909, Curitiba, available at: http://www.dsr.inpe.br/sbsr2011/files/p1414. pdf (last access: 19 February 2014), 2011.

Rollenbeck, R.: Global sources-local impacts: natural and anthropogenic sources of matter deposition in the Andes of Ecuador, Geo-öko, 31, 5-27, 2010.

Rollenbeck, R., Fabian, P., and Bendix, J.: Precipitation dynamics and chemical properties in tropical mountain forests of Ecuador, Adv. Geosci., 6, 73-76, doi:10.5194/adgeo-6-73-2006, 2006.

Rollenbeck, R., Bendix, J., Fabian, P., Boy, J., Wilcke, W., Dalitz, H., Oesker, M., and Emck, P.: Comparison of different techniques for the measurement of precipitation in tropical montane rain forest regions, J. Atmos. Ocean. Technol., 24, 156-168, doi:10.1175/JTECH1970.1, 2007.

Rollenbeck, R., Bendix, J., and Fabian, P.: Spatial and temporal dynamics of atmospheric water inputs in tropical mountain forests of South Ecuador, Hydrol. Process., 25, 344-352, doi:10.1002/hyp.7799, 2011.

Rudel, T. K., Coomes, O. T., Moran, E., Achard, F., Angelsen, A., $\mathrm{Xu}, \mathrm{J}$., and Lambin, E.: Forest transitions: towards a global understanding of land use change, Glob. Environ. Chang., 15, 23 31, doi:10.1016/j.gloenvcha.2004.11.001, 2005.

Schemenauer, R., Banic, C., and Urquizo, N.: High elevation fog and precipitation chemistry in southern Quebec, Canada, Atmos. Environ., 29, 2235-2252, 1995.

Schemenauer, R. S. and Cereceda, P.: A proposed standard fog collector for use in high-elevation regions, J. Appl. Meteorol., 33, 1313-1322, 1994.

Sigha-Nkamdjou, L., Galy-Lacaux, C., Pont, V., Richard, S., Sighomnou, D., and Lacaux, J.: Rainwater chemistry and wet deposition over the equatorial forested ecosystem of Zoétélé (Cameroon), J. Atmos. Chem., 46, 173-198, 2003.

Smith, S. J., van Aardenne, J., Klimont, Z., Andres, R. J., Volke, A., and Delgado Arias, S.: Anthropogenic sulfur dioxide emissions: 1850-2005, Atmos. Chem. Phys., 11, 1101-1116, doi:10.5194/acp-11-1101-2011, 2011.

Stevenson, D. S., Johnson, C. E., Collins, W. J., and Derwent, R. G.: The tropospheric sulphur cycle and the role of vol- 
canic $\mathrm{SO}_{2}$, Geol. Soc. London, Spec. Publ., 213, 295-305, doi:10.1144/GSL.SP.2003.213.01.18, 2003.

Stuefer, M., Freitas, S. R., Grell, G., Webley, P., Peckham, S., McKeen, S. A., and Egan, S. D.: Inclusion of ash and $\mathrm{SO}_{2}$ emissions from volcanic eruptions in WRF-Chem: development and some applications, Geosci. Model Dev., 6, 457-468, doi:10.5194/gmd6-457-2013, 2013.

Torres, O., Chen, Z., Jethva, H., Ahn, C., Freitas, S. R., and Bhartia, P. K.: OMI and MODIS observations of the anomalous 20082009 Southern Hemisphere biomass burning seasons, Atmos. Chem. Phys., 10, 3505-3513, doi:10.5194/acp-10-3505-2010, 2010. van der Werf, G. R., Randerson, J. T., Giglio, L., Collatz, G. J., Mu, M., Kasibhatla, P. S., Morton, D. C., DeFries, R. S., Jin, Y., and van Leeuwen, T. T.: Global fire emissions and the contribution of deforestation, savanna, forest, agricultural, and peat fires (19972009), Atmos. Chem. Phys., 10, 11707-11735, doi:10.5194/acp10-11707-2010, 2010.

Wullaert, H., Homeier, J., Valarezo, C., and Wilcke, W.: Response of the $\mathrm{N}$ and $\mathrm{P}$ cycles of an old-growth montane forest in Ecuador to experimental low-level $\mathrm{N}$ and $\mathrm{P}$ amendments, For. Ecol. Manage., 260, 1434-1445, doi:10.1016/j.foreco.2010.07.021, 2010. 